\title{
MINIREVIEW
}

\section{DEGRADATION AND CLEARANCE OF ATRIAL NATRIURETIC FACTORS (ANF)}

\author{
Alexander L. Gerbes and Angelika M. Vollmar \\ Dept. of Medicine II, Klinikum Großhadern, University of Munich and Dept. of \\ Pharmacology, Toxicology and Pharmacy, University of Munich, Munich, Fed. Rep. of \\ Germany.
}

(Received in final form July 24, 1990)

\begin{abstract}
Summary
Atrial natriuretic factor, the first well defined natriuretic hormone is synthesized in the human heart as 151 aminoacid (AA) preprohormone and stored as $126 \mathrm{AA}$ prohormone in atrial granules. Upon appropriate stimulation, the prohormone is cleaved into a $98 \mathrm{AA} \mathrm{N}$-terminal fragment and a 28 AA C-terminal fragment, the biological active ANF(99-126), both circulating in plasma. Circulating ANF(99-126) is cleared by various organs, such as lung, liver and intestine, kidney and upper and lower limbs. Reported arterial-venous extraction ratios vary greatly, but are not much different between organs, the average extraction ratio being about $35 \%$. Due to marked differences of organ blood flow, the contribution of various organs to total body ANF clearance differs considerably. Major mechanisms for ANF clearance are uptake by clearance receptors and degradation by an endoprotease (EC 3.4.24.11.). Clearance receptors, distinct from the receptors mediating the biological actions of ANF, have been demonstrated in various organs. Characterization of the ANF degrading enzyme activity has been performed in kidney tissue. Whether and how pathophysiological states affect ANF clearance is still poorly understood. Inhibition of clearance by ANF analogues binding to clearance receptors and by inhibitors of degrading peptidase can increase the biological action of circulating ANF. This may prove to be a therapeutic approach in diseases with smooth muscle contraction or volume overload.
\end{abstract}

Atrial natriuretic factor is the first well-defined natriuretic hormone. The best characterized pharmacological and partly physiological actions of ANF are natriuresis, diuresis and smooth muscle relaxation (for review see ref. 1-12). Recently, evidence has been provided that ANF might be involved in various other biological actions apart from its role in volume homeostasis such as immune or reproductive functions (13-17). ANF is synthesized in the human heart as a 151 amino acid pre-prohormone and stored as a 126 amino acid prohormone. Upon appropriate stimulation, such as atrial stretch, the prohormone is cleaved into an N-terminal and C-terminal fragment. The latter has been identified as the circulating bioactive ANF(99-126) $(18,19)$. A body of investigations has concentrated on the mechanisms of ANF release and on its biological actions (for review 1-14). So far, there is much less information on the processing of ANF prohormone as well as on the clearance of bioactive ANF. However, these seem to be topics of considerable interest, since plasma levels and biological activity of ANF are significantly influenced by these processes. This review article will concentrate on the mechanisms of degradation and clearance of bioactive ANF, including pathophysiological aspects and possible therapeutic implications. The still poorly understood metabolism of ANF in the central nervous system will not be addressed in this article. 


\section{Organ clearance}

Plasma levels of bioactive ANF are determined by both, release and clearance. While there is a rich body of information about ANF release, the number of studies on the clearance of this peptide is rather limited (20-36). The ability of various organs to clear ANF from the circulation can be described by the extraction ratio or by the organ clearance. The extraction ratio is calculated as arterial minus venous blood concentration over arterial blood concentration (\%). Multiplication of the extraction ratio with the organ plasma flow results in the organ clearance (liter/min). Several aspects and possible pitfalls have to be taken into consideration, regarding studies on ANF metabolism. Since the studies necessarily apply venous, and partly even arterial catheterization, for ethical reasons many investigations have been done in patients with hypertension or congestive heart failure rather than in healthy subjects. Some of the studies did not determine organ plasma flow, thus restricting their results to extraction ratios. Extraction ratios as well as organ clearance have been determined both under basal conditions and following intravenous ANF administration. For clearance determinations of pharmacologically active ANF doses, specific attention should be paid to the rate of infusion in order to achieve steady state conditions. Problems may arise by inappropriate intervals of plasma sampling. Furthermore, administration of ANF may decrease blood pressure (29), affect cardiac output and organ blood flow and increase glomerular filtration rate; this might result in under- or overestimation of ANF clearance as compared to physiological conditions. Furthermore, some studies are based on the assumption, that there is no pulmonary extraction of ANF. However, there is now evidence obtained by pulmonary wedge or pulmonary venous sampling $(20,21)$, that the lung is an important site for ANF extraction.

With these reservations in mind, it seems, that there is no major organ specificity for ANF extraction. Lung, liver, kidney, intestine and lower limb show similar extraction ratios within the respective studies. Values reported, however, differ considerably between various studies (Table 1) $(20-24,26,27,29,31-34,36)$. Extraction ratios were reported to be $0 \%-33 \%$ for lung, $22 \%-75 \%$ for liver and intestine, $23 \%-67 \%$ for kidney and $15 \%-61 \%$ for the lower limb. Taken together, it seems, that there is a general arterio-venous organ extraction ratio for ANF of about 35\%. Since there are marked differences of organ blood flow, obviously total ANF clearance differs considerably between various organs. Few investigations have determined organ blood flow together with ANF extraction under physiological or steady-state conditions $(20,22,24,29)$. About $50 \%$ of the total body clearance of ANF seems to be furnished by the lung (20). The renal (around 15\%) $(20,22,24)$ and splanchnic-hepatic (about $20 \%)(20,22,29)$ vascular beds also contribute significantly to ANF clearance. Several mechanisms could account for the above mentioned organ clearance of ANF: receptor-mediated uptake, enzymatic degradation or organspecific excretion (urine, bile). However, there are only few reports of concentrations of ANF in bile (20) or urine $(30,35)$. Therefore, organ specific excretion will not be covered in this article.

\section{Enzymatic degradation}

Since the kidney is a major target organ for ANF, interest has focussed on this organ not only as a site for receptor mediated clearance of this peptide, but also as a tissue which may be able to enzymatically degrade circulating ANF(99-126). Peptidase degradation of ANF is considered to play an important role among possible clearance mechanisms $(37,38)$. The brush border of the renal proximal tubule is known to be very rich in peptidases. These enzymes are membrane bound and their active sites face the lumen of the tubule (39). Incubating ANF(99-126) with these kidney microvilli results in a major degradation product cleaved between cysteine and phenylalanine (Cys 105-Phe 106) $(37,38,40-42$ ). Since the intact ring structure of ANF(99-126) is essential for its biological activity $(43,44)$, ANF is effectively inactivated by this cleavage process.

The properties of the ANF degrading activity have been investigated by several groups. The responsible substance is a glycoprotein $(37,40,42)$ with a molecular weight of approximately $94 \mathrm{kD}$, sensitive to metalloendoprotease inhibitors such as phosphoramidon and thiorphan. In view of these findings, the major proteolytic enzyme responsible for the ANF cleavage 


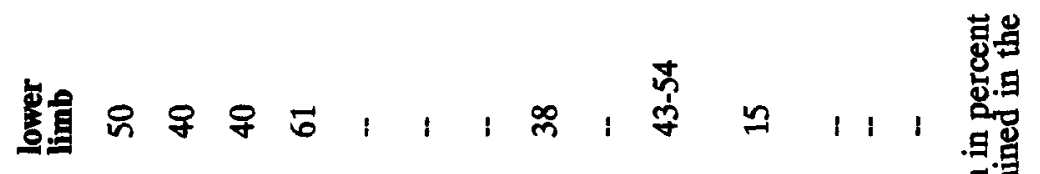

$$
\begin{aligned}
& \text { 退是 }
\end{aligned}
$$

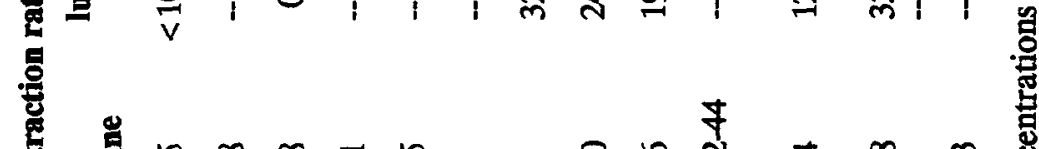

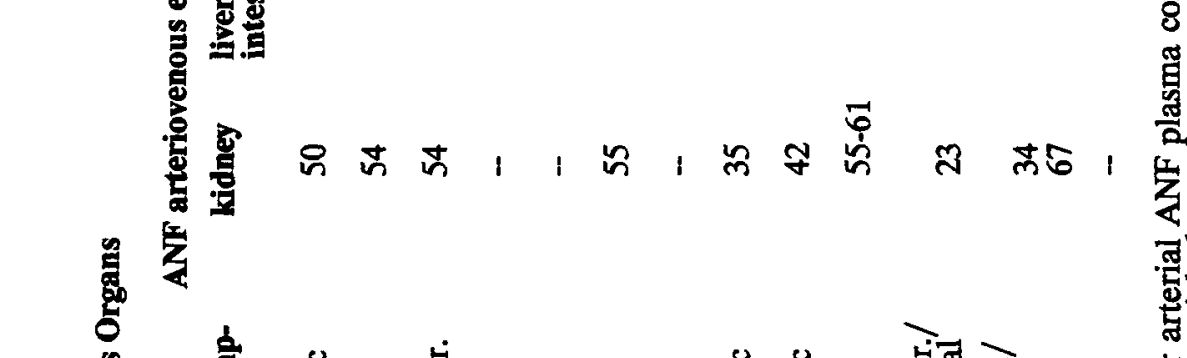

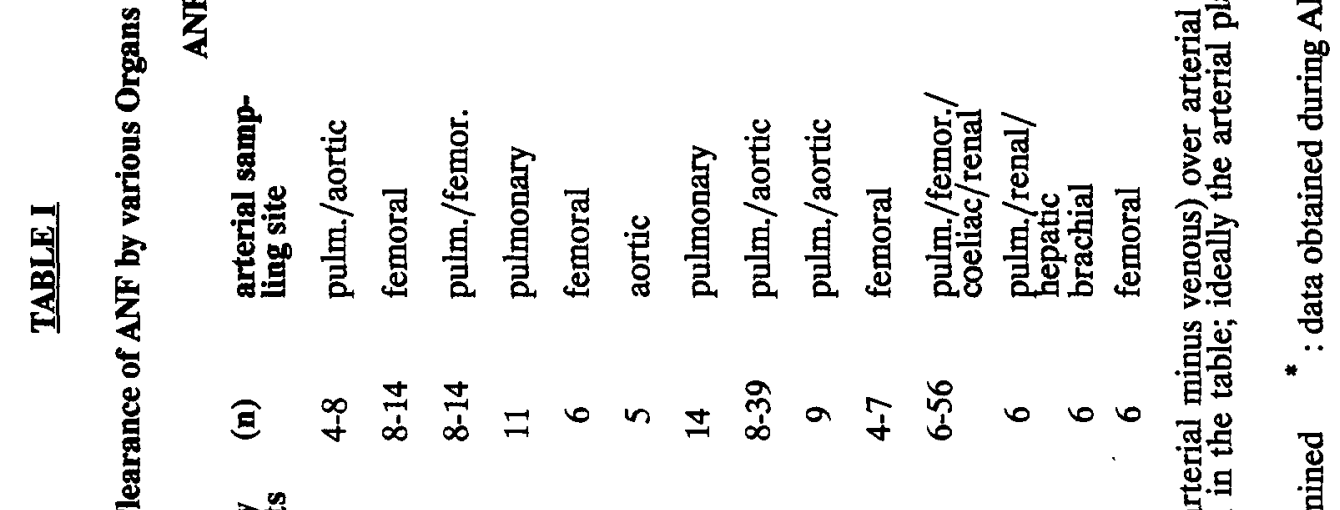

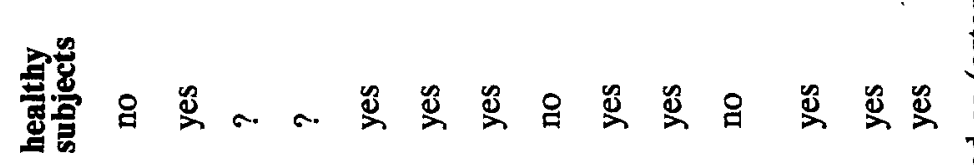

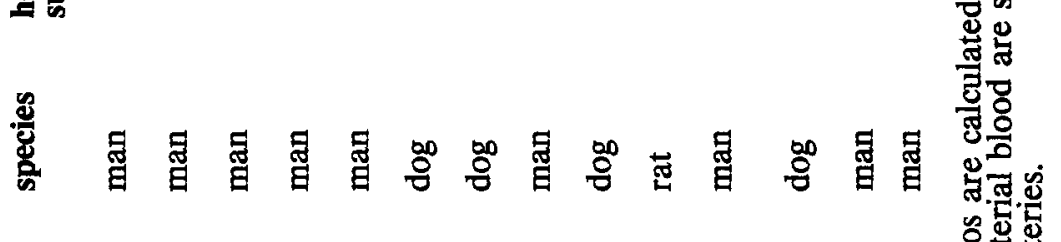

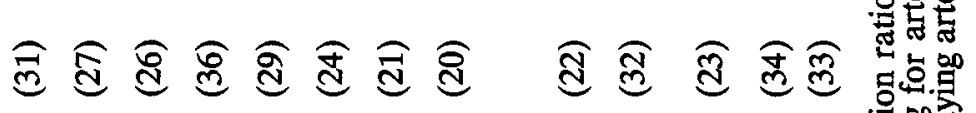

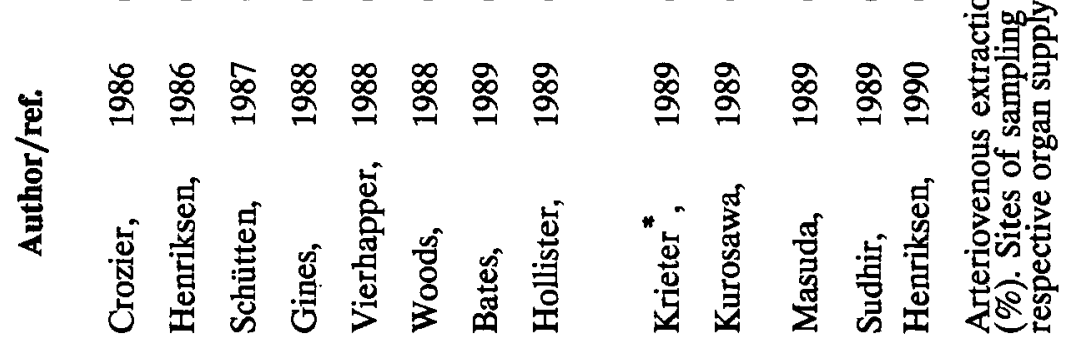


seems to be the endoprotease EC 3.4.24.11 (37,40,42). EC 3.4.24.11 has been reported also to possess enkephalin degrading activity (45). However, there may be various forms of $\mathrm{EC}$ 3.4.24.11, differing in cleavage site specificity and tissue distribution $(40,46-50)$. Thus, one may speculate that the kidney possesses a specific type of endoprotease EC 3.4.24.11. Apart from the major cleavage site within the loop structure, secondary attack by aminopeptidases has been hypothesized (37). These enzymes are not initially responsible for degradation, because specific inhibitors like captopril or amastatin had no significant effect (37). After the major cleavage process at the Cys-Phe bond of the ring structure, more complex degradation processes seem to follow, producing smaller ANF fragments (41). The major sites of renal ANF degradation by the endopeptidase seem to be the proximal tubule and the glomerulus (51). Prompted by these observations, efforts have been made to develop ANF analogues, which are resistent to this enzyme, as well as specific enzyme inhibitors, which could be therapeutically employed. Recent reports indicate ANF degrading activity by the vasculature (52) and the adrenal capsule (46). No information is available about the enzymatic degradation activity of other organs reported to contribute to ANF clearance.

\section{Clearance receptors}

Specific binding sites for atrial natriuretic factor have been identified on various cells, such as endothelial cells, vascular smooth muscle cells, inner medullary collecting duct cells and in various organs, such as lung, kidney, adrenal gland, liver and intestine (53-55). Several observations demonstrate that there are at least two different types of ANF receptors with different molecular size and different biological properties (56-61). The development of truncated ANF analogues which selectively bind to one receptor type such as des $(18-22)]-$ rANF(4-23)- $\mathrm{NH}_{2}(62,63)$, recently has allowed for better quantitative discrimination of both receptors. The current concept of both receptors is as follows: the $130 \mathrm{kD}$ receptor exhibits a higher affinity for circulating biologically active ANF, is coupled to guanylate cyclase and mediates the biological effects. Thus it has been called B- (Biological)- or $\mathrm{R}_{1}$-receptor. The other receptor type shows a molecular weight of $65 \mathrm{kD}$, exhibits a lower affinity to biologically active ANF and binds truncated ANF analogues; it has thus been called C(Clearance)- or $R_{2}$-receptor (64-67). C-receptors might mediate suppression of adenylate cyclase activity by ANF $(68,69)$. Interestingly, it has been shown that the C-receptor may regulate the biologic activity of endogenously released ANF (67), and there is evidence, that this receptor type indeed has a clearance function (64).

In anesthetized rats, administration of an ANF analogue selectively binding to C-receptors, induced marked dose-dependent increases of ANF (99-126) plasma concentration, and decreases of its volume of distribution and metabolic clearance rate. Furthermore, there is evidence, that a major part of ANF metabolism is due to an internalization following the binding of circulating ANF to the C-receptor and subsequent intralysomal hydrolysis (64). The regulation of the C-receptor is poorly understood. There is evidence, that maneuvres decreasing intravascular volume decrease ANF plasma levels and in turn increase total ANF receptor density (70-72). Surprisingly, this increase of ANF receptor density is coupled to a reduced biological response to ANF. The observation, that C-receptors but not Breceptors are augmented following dehydration (73) could explain this seeming contradiction and indicates that regulation of C-receptor density might be involved in volume homeostasis. There are few data on the quantitative relationship between B- and Creceptors in various tissues. In the kidney, in particular on glomeruli, the majority of ANF receptors seems to be of the clearance type $(73,74)$. The same has been observed on cultured bovine aorta endothelial cells $(56)$, on adrenal zona glomerulosa cells (74) and on lung membranes (61). These recent observations are compatible with the concept of a functional importance of the C-receptors, which are distinctly different from the Breceptors, in the clearance of ANF - a rather unique mechanism in the metabolism of peptides.

\section{Pathophysiology}

Elevated plasma concentrations of ANF have been found in various pathophysiological states, such as congestive heart failure, renal failure and in some patients with liver disease (e.g. 75-78). An increased release of ANF has been suggested in these diseases $(36,79-82)$. However, elevated plasma concentrations might also be caused by decreased clearance. To 
date, little is known about clearance in pathophysiological states. Recently, it has been reported, that the fractional extraction of various organs is unchanged in patients with liver cirrhosis (27). In an experimental model it has been shown that the renal clearance of ANF varies considerably, depending upon glomerular filtration rate (24); thus, augmented ANF plasma concentrations in renal diseases might be partly due to reduced ANF elimination. The proportion of B- and C-receptors for ANF in aorta, adrenal and kidney seems unchanged in experimental congestive heart failure (74). In an experimental model of cirrhosis, C-receptor density on glomeruli was increased, whereas B-receptors tended to be decreased (83); however, these animals were not investigated for ANF clearance. Clearly, there is a need for further investigations on whether and how metabolic clearance and degradation of ANF is affected by pathophysiological states.

\section{Therapeutic implications}

Beneficial effects of ANF application have been reported in congestive heart failure, hypertension, renal failure, chronic obstructive lung disease and liver disease (84-91). Augmented circulating levels of ANF may be achieved by exogenous administration of ANF. Due to the peptide character of the substance, ANF can be administered only intravenously. The rapid metabolic clearance (92-94) makes repeated bolus injections or continuous infusions necessary. Alternatively, circulating ANF concentrations might be elevated by blocking its clearance. This might be achieved by administering truncated analogues, binding to clearance receptors only and thus augmenting the concentration of ANF reaching the B-receptors $(64,67,95)$. Furthermore, inhibitors of the ANF degrading peptidase might show the same results. Indeed, several investigations employing endopeptidase EC 3.4.24.11 inhibitors $(95-105)$, showed that the circulating ANF immunoreactivity was elevated and this was accompanied by an augmented biological activity, such as increased urinary volume and sodium excretion. Interestingly, these chemicals seem to be especially useful in pathophysiological conditions. They have been shown to enhance the biological activities (natriuretic and depressor responses) of ANF in experimental models of hypertension $(97,103-105)$ and volume expansion (101). Further investigations will evaluate the potential of this rather elegant therapeutic approach.

\section{Acknowledgments}

Jens H. Henriksen, M.D., Univ. of Copenhagen, Denmark and William R. Samson, Ph.D., Univ. of Missouri-Columbia, U.S.A are thanked for critical reading of the manuscript. M. Hummel and M. Raab are thanked for preparation of the manuscript. The work of one author (A.G.) has been supported by a grant (Asche Stipendium) from the Deutsche Gesellschaft für Verdauungs- und Stoffwechselkrankheiten.

\section{References}

1. J.V. ANDERSON and S.R. BLOOM, J. Endocrin. 110 7-17 (1986).

2. R.M. ARENDT and A.L. GERBES, Dtsch. med. Wschr. 111 1849-1857 (1986).

3. B.J. BALLERMANN and B.M. BRENNER, J. Clin. Invest. 76 2041-2048 (1985).

4. M. CANTIN and J. GENEST, Sci. Am. 254 76-81 (1986).

5. A.J. DE BOLD, Federation Proc. 45 2081-2085 (1986).

6. E.A. ESPINER and A.M. RICHARDS, Lancet 707-710 (1989).

7. T. INAGAMI, J. Biol. Chem. 1989; 264:3043-3046.

8. R.E. LANG, T. UNGER and D. GANTEN, J. Hypertens. 5 255-271 (1987).

9. J.H. LARAGH and S.A. ATLAS, Kidney Intern. 34 S64-S71 (1988).

10. P.J. NEEDLEMAN and J.E. GREENWALD, N. Engl. J. Med. 314 828-834 (1986).

11. G. THIBAULT, R. GARCIA, J. GUTKOWSKA, J. GENEST and M. CANTIN, Drugs 31 369-375 (1986).

12. N.C.TRIPPODO, Hypertension 10(suppl.I) I122-I127 (1987).

13. VOLLMAR AM, Klin. Wochenschr., in press.

14. J. GUTKOWSKA and M. NEMER, Endocrine Rev. 10 519-536 (1989).

15. A.M. VOLLMAR and R. SCHULZ, Endocrinology, in press (1990).

16. A.M. VOLLMAR, C. MYTZKA, R.M. ARENDT and R. SCHULZ, Endocrinology $123762-767$ (1988).

17. A.M. VOLLMAR, A. FRIEDRICH, F. SINOWATZ and R. SCHULZ, Peptides 9 965-971 (1988). 
18. M. SUGIYAMA, H. FUKUME, R.T. GAMMER, K.S. MISONO, Y. YABE, Y. MORISAWA and T. INAGAMI, Biochem. Biophys. Res. Comm. 123 338-344 (1984).

19. D. SCHWARTZ, D.M. GELLER, P.T. MANNING, N.R.SIEGEL, K.R. FOK, C.E. SMITH and P. NEEDLEMAN, Science $229397-400$ (1985).

20. A.S. HOLIISTER, R.J. RODEHEFFER F.J. WHITE, J.R. POTTS, T. IMADA and T. INAGAMI, J. Clin. Invest. 83 623-628 (1989).

21. E.R. BATES, M.J. MCGILLEM, J. MANCINI and R.J. GREKIN, Am. J. Cardiol. 63 372-373 (1989).

22. P.A. KRIETER and A.J. TRAPANI, Drug Metab. Dispos. 17 14-19 (1989).

23. T. MASUDA, M. SHICHIRI and F. MARUMO, Acta Endocrinol. 120 170-174 (1989).

24. R.L. WOODS, Am. J. Physiol. 255 E934-E941 (1988).

25. T. YUKIMURA, K. ITO, K. MIURA and K. YAMAMOTO, J. Hypertension 4(suppl.6) S532-S534 (1986).

26. H.J. SCHUTTEN, J.H. HENRIKSEN and J. WARBERG, Clin. Physiol. 7 125-132 (1987).

27. J.H. HENRIKSEN, H.J. SCHÜTTEN, F. BENDTSEN and J. WARBERG, Liver $\underline{6}$ 361-368 (1986).

28. J. TANG, R.J. WEBBER, D. CHANG, J.K. CHANG, J. KIANG and E.T. WEI, Regulatory Peptides 2 53-59 (1984).

29. H. VIERHAPPER, S. GASIC, P. NOWOTNY and W. WALDHÄUSL, Metabolism 37 973-975 (1988).

30. F. MARUMO, H. SAKAMOTO, K. ANDO, T. ISHIGAMI and M. KAWAKAMI, Biochem. Biophys. Res. Comm. 137 231-236 (1986).

31. I.G. CROZIER, M.G. NICHOLIS, H. IKRAM, E.A. ESPINER, T.G. YANDLE and S. JANS, Hypertension 8(suppl.II) 11-15 (1986).

32. T. KUROSAWA, S. HIRAMATSU, Y. KATOH, R. KIKAWADA and F. MARUMO, Jpn. Circ. J. 53 779-785 (1989).

33. J.H. HENRIKSEN, F. BENDTSEN and A.L. GERBES, Metabolism, in press.

34. K. SUDHIR, P. FRIBERG, I.T. MEREDITH, R.L. WOODS, M.D. ESLER and G.L. JENNINGS, Clin. Sci. 77 605-610 (1989).

35. K. ANDO, N. UMETANI, T. KUROSAWA, S. TAKEDA, Y. KATOH and F. MARUMO, Klin. Wochenschr. 66 768-772 (1988).

36. P. GINES, W. JIMENEZ, V. ARROYO, M. NAVASA, C. LOPEZ, L. TITO, A. SERRA, J. BOSCH, G. SANZ, F. RIVERA and J. RODES, Hepatology 8 636-642 (1988).

37. S.L. STEPHENSON and A.J. KENNY, Biochem. J. 243 183-187 (1987).

38. G.M. Olins, K.L. Spear, N.R. Siegel, E.J. Reinhard and H.A. Zurcher-Neely, Eur. J. Biochem. 170 431-434 (1987).

39. A.J. KENNY and S. MAROUX, Physiol. Rev. 62 91-118 (1982).

40. P. BERTRAND and A. DOBLE, Biochem. Pharmacol. $373817-3821$ (1988).

41. J.A. KOEHN, B.N. NORMAN, L. JONES, L. LESUEUR, Y. SAKANE and R.D. GHAI, J. Biol. Chem. 262 11623-11627 (1987).

42. J.L. SÓNNENBERG, Y. SAKANE, A.Y JENG, J.A. KOEHN, J.A. ANSELL, L.P. WENNOGLE and R.D. GHAI, Peptides 9 173-180 (1988).

43. K.S. MISONO, H. FUKUMI, R.T. GRAMMER and T. INAGAMI, Biochem. Biophys. Res. Comm. 119 524-529 (1984).

44. L. CHARTIER, E. SCHIFFRIN and G. THIBAULT, Biochem. Biophys. Res. Comm. 122 171-174 (1984).

45. I.S. FULCHER, R. MATSAS, J. TURNER and A.J. KENNY, Biochem. J. 203 519$522(1982)$.

46. R.J. SCHIEBINGER, J.H. PRATT and D.C. KEM, Endocrinology 1988; 123:492497.

47. C. LIEORENS and J.C. SCHWARTZ, Eur. J. Pharmacol. 69 113-116 (1981).

48. R. MATSAS, I.S. FULCHER, A.J. KENNY and A.J. TURNER, Proc. Natl. Acad. Sci. USA 80 3111-3115 (1983).

49. R. MATSAS, A.J. KENNY and A.J. TURNER, Biochem. J. 223:433-440 (1984).

50. R. MATSAS, A.J. TURNER and A.J, KENNY, FEBS Lett. 175 124-128 (1984).

51. M. SHIMA, Y. SEINO, S. TORIKAI and M. IMAI, Life Sci. 43 357-363 (1988).

52. P.P. TAMBURINI, J.A. KOEHN, J.P. GILLIGAN, D. CHARLES, R.A. PALMESINO, R. SHARIF, C. MCMARTIN, M.D. ERION and M.J.S. MILLER, J. Pharm. Exp. Ther. 251 956-961 (1989). 
53. C.R. MANTYH, L. KRUGER, N.C. BRECHA and P.W. MANTYH, Hypertension 8 712-721 (1986).

54. C. BIANCHI, J. GUTKOWSKA, G. THIBAULT, R. GARCIA, J. GENEST and M. CANTIN, Histochemistry $82441-452$ (1985).

55. R.E. STEWART, S.E. SWITHERS, L.M. PLUNKETT and R. MCCARTHY, Biobehav. Rev. 12 151-168 (1988).

56. D.C. LEITMAN, J.W. ANDRESEN, T. KUNO, Y. KAMISAKI, J.K. CHANG and F. MURAD, J. Biol. Chem. 261 11650-11655 (1986).

57. C. KOSEKI, Y. HAYASHI, N. OHNUMA and M. IMAI, Biochem. Biophys. Res. Comm. 136 200-207 (1986).

58. K. PANDEY and T. INAGAMI, J. Hypertens. 6(suppl.4) S292-S294 (1988).

59. J. FETHIERE, S. MELOCHE, T.T NGUYEN, H. ONG and A. DE LEAN, Mol. Pharmacol. 35 584-592 (1989).

60. R. TAKAYANAGI, R.M. SNAJDAR, T. IMADA, M. TAMURA, M. PANDEY, K.S. MISONO and T. INAGAMI, Biochem. Biophys. Res. Comm. 144 244-250 (1987).

61. J.G. PORTER, Y. WANG, K. SCHWARTZ, A ARFSTEN, A. LOFFREDO, $K$. SPRATT, D.B. SCHENK, F. FULLER, R.M. SCARBÓROUGH and J.A. LEWICKI, J. Biol. Chem. 263 18827-18833 (1988).

62. R.M. SCARBOROUGH, D.B. SCHENK, G.A. MCENROE, A. ARFSTEN, L.L KANG, K. SCHWARTZ and J.A. LEWICKI, J. Biol. Chem. 261 12960-12964 (1986).

63. G.M. OLINS, D.R. PATTON, P.R. BOVY and P.P. MEHTA, J. Biol. Chem. 263 10989-10993 (1988).

64. F.A. ALMEIDA, M. SUZUKI, R.M. SCARBOROUGH, J.A. LEWICKI and T. MAACK, Am. J. Physiol. 256 R469-R475 (1989).

65. M. CHINKERS, D.L. GARBERS, M.S. CHANG, D.G. LOWE, H. CHIN, D.V. GOEDDEL and S. SCHULZ, Nature 338 78-83 (1989).

66. A. DE LEAN, P. VINAY and M. CANTIN, FEBS Lett 193 239-242 (1985).

67. T. MAACK, M. SUZUKI, F.A. ALMEIDA, D. NUSSENZVEIG, R.M. SCARBOROUGH, G.A. MCENROE and J.A. LEWICKI, Science 238 675-678 (1987).

68. M.B. ANAND-SRIVASTAVA, A.K. SRIVASTAVA and M. CANTIN, J. Biol. Chem. 262 4931-4934 (1987).

69. M.B. ANAND-SRIVASTAVA, M. R. SAIRAM and M. CANTIN, J. Biol. Chem. 265 8566-8572(1990).

70. B.J. BALLERMANN, R.L. HOOVER, M.J. KARNOVSKY and B.M. BRENNER, J. Clin. Invest. 76 2049-2056 (1985).

71. V. CACHOFEIRO, E.L. SCHIFFRIN, M. CANTIN and R. GARCIA, Am. J. Physiol. 256 R1250-R1257 (1989).

72. A. HINKO, M. THIBONNIER and J.P. RAPP, Biochem. Biophys. Res. Comm. 144 1076-1083 (1987).

73. M.C. KOLLENDA, A.M. VOLLMAR, G.A. MCENROE and A.L. GERBES, Am. J. Physiol. 258 R 1084-1088 (1990).

74. C. BIANCHI, G. THIBAULT, E. WROBEL-KONRAD, E. DE LEAN, J. GENEST and M. CANTIN, Am. J. Physiol. 257 F515-F523 (1989).

75. A.L. GERBES, R.M. ARENDT and G. PAUMGARTNER, J. Hepatol. 5 123-132 (1987).

76. R.M. ARENDT, A.L. GERBES, D. RITTER, E. STANGL, P. BACH and J. ZÄHRINGER, J. Hypertens. 4(suppl.2) S131-S135 (1986).

77. H.G. PREDEL, A. BACKER, J. RIPNOWSKI, R. DUSING and H.J. KRAMER, Klin. Wochenschr. 65(suppl.8) 127-132 (1987).

78. A.E.G. RAINE, P. ERNE, E. BURGISSER, F.B. MÜLLER, P. BOLLI, F. BURKART and F.R. BÜHLER, N. Engl. J. Med. 315 533-537 (1986).

79. M. CANTIN, G. THIBAULT, J. DING, J. GUTKOWSKA, R. GARCIA, G. JASMIN, P. HAMET and J. GENEST, Am. J. Pathol. 130 552-568 (1988).

80. K. HASEGAWA, Y. MATSUSHITA, T. INOUE, H. MORII, M. ISHB́BASH and T. YAMAJI, J. Clin. Endocrinol. Metab. 63 819-822 (1986).

81. R.E. LANG, R. DIETZ, A. MERKEL T. UNGER, H. RUSKOAHO and D. GANTEN, J. Hypertens. 4(suppl.2) S119-S123 (1986).

82. H. DREXILR, J. HANZE, M. FINCKH, W. LU, H. JUST and R.E. LANG, Circulation 79 620-633 (1989). 
83. A.L. GERBES, M.C. KOLLENDA, A.M. VOLLMAR, J. REICHEN, N. VAKIL and R.M. SCARBOROUGH, Hepatology 10588 (1989).

84. K. SCHAFFERHANS, E. HEIDBREDER, S. SPERBER, J. DÄMMRICH and A. HEIDLAND, Kidney Intern. 34(suppl.25) S101-S103 (1988).

85. A.L. GERBES, R.M. ARENDT, E. STANGL, V. GULBERG, T. SAUERBRUCH, D. JÜNGST and G. PAUMGARTNER. Functional Morphology of the Endocrine Heart, W.G. Forssmann, D.W. Scheuermann, J. Alt (eds), 229-234, Steinkopff, Darmstadt (1988).

86. G. LAFFI, M. PINZANI, E. MEACCI, G. LaVILLA, D. RENZI, E. BALDI, F. COMINELLI, F. MARRA and P. GENTILINI, Gastroenterology 96 167-177 (1989).

87. S. ADNOT, P. ANDRIVET, P.E. CHABRIER, J. PIOUET, P. PLAS, P. BRAQUET, F. ROUDOT-THORAVAL and C. BRUN-BUISSON, J. Clin. Invest. 83 986-993 (1989).

88. A.M. RICHARDS, M.G. NICHOLLS, E.A. ESPINER, H. IKRAM, T.G. YANDLE, S.L. JOYCE and M.M. CULLENS, Hypertension 7 812-817 (1985).

89. R.J. CODY, S.A. ATLAS, J.H. LARAGH, S.H. KUBO, A.B. COVIT, K.S. RYMAN, A. SHAKNOVICH, K. PONDOLFINO, M. CLARK, M.J.F. CAMARGO and R.M. SCARBOROUGH, J. Clin. Invest. 78 1362-1374 (1986).

90. Y. SAITO, K NAKAO, K. NISHIMURA, A. SUGAWARA, K. PKUMURA, $K$. OBATA, R. SONODA, T. BAN, H. YASUE and H. IMURA, Circulation 76 115124 (1987).

91. G.A.J. RIEGGER, E.P. KROMER and K. KOCHSIEK, J. Cardiovasc. Pharmacol. 8 1107-1112 (1986).

92. K. NAKAO, A. SUGAWARA, N. MORII, M. SAKAMOTO, T. YAMADA, H. ITOH, S. SHIONO, Y. SAITA, K. NISHIMURA, T. BAN, K. KANGAWA, $H$. MATSUO and H. IMURA, Eur. J. Clin. Pharmacol. 31 101-103 (1986).

93. F.C. LUFT, R.E. LANG, G.R. ARONOFF, H. RUSKOAHO, M. TOTH, D. GANTEN, R.B. STERZEL and T. UNGER, J. Pharmacol. Exp. Ther. 236 416-418 (1986).

94. K.K. MURTHY, G. THIBAULT, E.L. SCHIFFRIN, R. GARCIA, L. CHARTIER, J. GUTKOWSKA, J. GENEST and M. CANTIN, Peptides 7 241-246 (1986).

95. J.P. KOEPKE, L.D. TYLLER, A.J. TRAPANI, P.R. BOVY, K.L. SPEAR, G.M. OLINS and E.H. BLAINE, J. Pharmacol. Exp. Ther. 249 172-176 (1989).

96. G.M. OLINS, P.A. KRIETER, A.J. TRAPANI, K.L. SPEAR and P.R. BOVY, Mol. Cell. Endocrinol. 61 201-208 (1988).

97. E.J. SYBERTZ, P.J.S. CHIU, S. VEMULAPALLI, B. PITTS, J. FOSTER, R.W. WATKINS, A. BARNETT and M.F. HASLANGER, J. Pharmacol. Exp. Ther. 250 624-631 (1989).

98. C. GROS, A. SOUQUE, J.C. SCHWARTZ, J. DUCHIER, A. COURNOT, P. BAUMER and J.M. LECOMTE, Proc. Natl. Acad. Sci. 86 7580-7584 (1989).

99. A.J. TRAPANI, G.J. SMITS, D.E. MCGRAW, K.L. SPEAR, J.P. KOEPKE, G.M. OLINS and E.H. BLAINE, J. Cardiovasc. Pharmacol. 14 419-424 (1989).

100. D.B. NORTHRIDGE, C.T. ALABASTER, J.M.C. CONNELL, S.G. DILLY, A.F. LEVER, A.G. JARDINE, P.L. BARCLAY, H.J. DARGIE, I.N. FINDLAY and G.M.R. SAMUUELS, Lancet ii 591-593 (1989).

101. H.M. LAFFERTY, G.M. GUNNIN, P. SILVA, M.B. ZIMMERMANN, B.M. BRENNER and S. ANDERSON, Circ. Res. 65 640-646 (1989).

102. A.J. TRAPANI, G.J. SMITS, D.E. MCGRAW, K.L. SPEAR, J.P. KOEPKE, G.M. OLINS and E.H. BLAINE, J. Cardiovasc. Pharmacol. 14 419-424 (1989).

103. R.L. WEBB, G.D. YASAY, C. MCMARTIN, R.B. MCNEAL and M.B. ZIMMERMANN, J. Cardiovasc. Pharmacol. 14 285-293 (1989).

104. A.A. SEYMOUR, J.N. SWERDEL, S.A. FENNELL, S.P. DRUCKMAN, R. NEUBECK and N.G. DELANEY, J. Cardiovasc. Pharmacol. 14 194-204 (1989).'

105. E.J. SYBERTZ, P.J.S. CHIU, S. VEMULAPALLI, R. WATKINS and M.F. HASLANGER, Hypertension 15 152-161 (1990). 